\title{
Alternative Water Heating Technologies Replaced Instantaneous Water Heater in Hotel Sector - a SWOT-AHP Analysis
}

\author{
Suttinee Jingjit ${ }^{1}$, Md Hafiz All Amin ${ }^{1,2}$, Kua-anan Techato ${ }^{3,4}$ \\ ${ }^{1}$ Faculty of Environmental Management, Prince of Songkla University, Hat Yai, 90110, Songkhla, Thailand \\ ${ }^{2}$ Agroforestry and Environment, Faculty of Agriculture, Hajee Mohammad Danesh Science and Technology University, \\ Dinajpur-5200, Bangladesh \\ ${ }^{3}$ Environmental Assessment and Technology for Hazardous Waste Management Research Center, \\ Faculty of Environmental Management, Prince of Songkla University, Hat Yai, 90110, Songkhla, Thailand \\ ${ }^{4}$ Center of Excellence on Hazardous Substance Management (HSM), Bangkok 10330, Thailand
}

\begin{abstract}
In pursue of energy-efficient alternative water heating options, a SWOT-AHP analysis was accomplished for Solar Water Heater (SWH) and Heat Pumps (HP) against instantaneous water heaters (IWH). The results show that the energy consumption and bills saving are dominant in strength of both HP and SWH. Financial and technological aspects seem to play a relatively significant role. Additionally, HP and SWH are more convenient for the energy consumption in water heating technology in hotel sector of Thailand. Finally, we can say that HP and SWH are more convenient for water heating system as compare to IWH.
\end{abstract}

Keywords - Water heating, Instant water heaters, Heat pump, Solar water heater and SWOT-AHP analysis.

DOI: 10.18421/TEM102-03

https://doi.org/10.18421/TEM102-03

Corresponding author: Kua-anan Techato,

Faculty of Environmental Management, Prince of Songkla University, Hat Yai, 90110, Songkhla, Thailand.

Center of Excellence on Hazardous Substance Management (HSM), Bangkok 10330, Thailand.

Email: kuaanan.t@psu.ac.th

Received: 02 January 2021.

Revised: 18 March 2021.

Accepted: 25 March 2021.

Published: 27 May 2021.

(c) BY-NC-ND (C) 2021 Suttinee Jingjit, Md Hafiz All Amin \& Kua-anan Techato; published by UIKTEN. This work is licensed under the Creative Commons AttributionNonCommercial-NoDerivs 4.0 License.

The article is published with Open Access at www.temjournal.com

\section{Introduction}

Thailand's Electricity Generation Authority (EGAT) covers $31 \%$ of electricity production, $27 \%$ of Independent Power Producers (IPP), 24\% of Small Power Producers (SPP), Relatively Small Power Producers (VSPP) and 13\% of electricity imported from other nations in 2018 [1]. In January 2016, the gross electricity generation capacity in Thailand was 39,756.45 Mega-Watt (M.W.) Around 70 percent of Thailand's electricity is produced from natural gas [2]. In recent years, the use of electricity in Thailand has continuously increased. In 2015, the country's overall usage 179,803 gigawatt-hours (GWh) viz. industrial sector $(76,914 \mathrm{GWh}, 42.4$ percent), the commercial sector $(61,446 \mathrm{GWh}, 33.9$ percent) and the residential sector $(41,443 \mathrm{GWh}, 22.8$ percent), rising by $2.6 \%$, compared with the previous year [3]. Hotels make up for a large 10 percent share of the electricity consumption of the commercial sector, which is one of the main areas of national electricity consumption [4]. There are 5,420 hotels in Thailand, based on study by Mahidol University in 2010. One third $(1,603)$ of all hotels are resort hotels. It leaps into double in the present as the number of tourists grows in extraordinary amount during the last decade. The Thailand Tourism Authority announced that Thailand has earned about THB 2,000 million a year since 2014, raising the overall Thai economy by 2.8 percent in tourism revenues, ranking it the 10th highest source of revenue [5]. In hotels and restaurants, which rose by 14 percent, the fastest growth was observed. The number of inbound visitors was 29.9 million people, a 20.4 percent rise. Tourism revenue amounted to 1,523.6 billion baht, a 22 percent rise. The rate of retaliation occupancy peaked at 61.7 percent [6]. The hotel \& restaurant industry has been reported to account for 3\%-4\% of the country's GDP between 2000 and 2015. The 
contribution of hotels and restaurants rose to $5 \%$ in 2016 and 2017. High growth rates in the tourism sector have resulted in substantial investments in the hotel industry in the region. As a result, energy demand rose by 5.08 per cent relative to the previous year [7]. This was driven by Chinese tourists who visited charter flights or low-cost airlines, as well as by Malaysian tourists who usually travel with their own cars. In addition, the fall in gasoline prices has boosted domestic travel. Tourism thus is the key force driving within the continuous development of the national economy and offsetting the fall in export revenues. In order to promote the expansion of tourism, which is the key engine of the Thai economy, the government and EGAT have to facilitate the growth and production of electricity generation capacity. On the other hand, one of the strategies for renewable energy growth is the elimination of excessive power use by the usage of alternative technology instead of old, obsolete technologies.

\subsection{Instantaneous Water Heater (IWH)}

Instant water heaters (IWH) are commonly used in household, resort, and hotel industries to produce hot water. IWH is used to produce water heating for everyday usage in Thailand, a tourism-based nation with several hotels for commercial purposes. As this technique is a water heater of demand form, it ensures that water is only heated as request; hot water is not retained for potential usage. With electricity of about 3.5-4.5 kilowatts (KW) [4], IWH raises large energy usage and generates high amounts of greenhouse gas emissions [8]. It involves several elements to heat the water to validate immediate hot water movement, making it complicated to build and expensive. Cold water reaches the heater if hot water is required in hotels, heated by three electrical resistive sections. The temperature rises subsequently as water flows over each area, giving the third system the required temperature for problematic use. The control board of the microprocessor adjusts the amount of energy used to heat the water at the temperature pre-set by the consumer. Since large volumes of hot water are absorbed in hotels at a given period, the instantaneous water heating device consumes a tremendous amount of energy [9]. To reduce the considerable amount of energy, greenhouse gas emission, and costing, the alternative water heating options Solar Water Heater (SWH) and Heat Pump (HP) have the ability to reduce energy usage by 2.4 to 4 times [10], [11]. The environmentalists are endeavoring to focus on the rational service of energy by offering the best benefit to maintaining environmental sustainability.

\subsection{Alternative Heating solutions}

Solar water heating (SWH) systems are a commonly accepted advantage of green technologies that can minimize the amount of electrical resources required for water heating. The SWH device produces end-use electricity savings of $12-20 \%$ of the gross electrical energy usage in Canada and Tunisia [12], although it can save roughly $50-85 \%$ in the USA [13]. Alternatively, the SWH promoted a major reduction of up to 70 percent in power peak demand for electricity [14]. These systems have achieved remarkable results in saving energy in many countries. The heat pump devices, utilizing general sources such as air, water, and dirt, heat the water. These devices will have the consequence of dramatically changing the curve of the energy load and reducing power peaks in comparison to electrical systems [15].

Alternative water heating solutions, SWH and heat pump devices, are the alternative to the environmental effects of fossil-based fuel usage that has become a current issue. SWH and the heat pump have been able to greatly decrease greenhouse gas emissions of $\mathrm{CO}_{2}$ [16]. Li et al. [17] found that a 1 $\mathrm{m}^{2}$ SWH collector region would decrease approximately $200 \mathrm{~kg}$ of $\mathrm{CO}_{2}$ emissions or it will save 67-70 percent of $\mathrm{CO}_{2}$ emissions relative to a traditional device. By changing water heating systems, $\mathrm{CO}_{2}$ emissions in Oman and Lebanon have been lowered by about 1.2 and 0.3 million tons each year, respectively [18]. In Asia, such as Taiwan and Korea, the ability to minimize $\mathrm{CO}_{2}$ pollution could reach 5.2 and 186 tons, respectively, by changing water heating technologies [19].

It should be instead of the previously described lower electric power such as SWH or heat pump. As energy bill saves, both alternate water heater systems are more appealing [18]. It has shown strong energy bill savings by the usage of these devices, such as in China, Tunisia and Taiwan. Although in South Africa, the power bill will hit 30 percent monthly savings from the usage of energy-backed SWH, and 47 percent in Brazil [20], [21]. In the U.S., after modifying water heating technology, a household will save $\$ 100-\$ 300$ in energy costs each year [22]. In Greece, the latest energy conservation software for the water heater device would reduce the power bill for thousands of customers [23]. The nation has saved millions of dollars in Lebanon by eliminating the expense of modern power stations and reducing the immense energy bill for the user [24]. Although SWH and heat pump investment costs are obviously large, their electric power is very low. The PP for SWH was found to be 7 years and for HP is very remarkable in Thailand from an economic study of water heating technologies for around 1 year [10]. 
With the quick payback time, buyer preference may be inspired by it.

Yet there are still several disadvantages of Substitute Water Heaters. Although the alternate water heating technology for energy saving is the SWH and heat pump, they are not commonly utilized because of the high cost of investment [25]. Due to the incredibly high cost of capital relative to traditional hot water heaters, the amount of their installations is reduced. It tends to be the most significant barrier to investment determination. SWH's funding expenses are 50-60\% more than IWH's [26]. The electronic water heater is almost 4 times cheaper than the heat pump [27]. It is complicated in the case of HP installation and requires a qualified professional; requires a condensate drain and frequent cleaning of air filters; cools and dehumidifies the room. The SWH solar monitoring device causes issues with operation and maintenance.

\subsection{Strategy to Tackle Impediments}

As stated before, the initial cost of the SWHs and HPs is far higher than the old water heating technologies, which makes it difficult to make an investment decision, especially the low-income hotel. One of the most significant variables for selection is government financial assistance [28]. To attract consumers, the financial assistance of government entities in terms of subsidies is deemed appropriate. In several nations, such as Germany, Austria, Sweden, Australia and the Netherlands, a subsidy program for alternate water heating technologies is being promoted. There are also several ventures for the government of Thailand to boost their investment. Next the revolving fund of ESCO (Grid Distribution Company) comes under the Ministry of Energy's Department of Renewable Energy Production and Performance (DEDE). The 1st ESCO fund discovered that there were 2 ventures requiring improvements in water heating technology. The 1st ESCO fund had a corpus of 13 million euros. Conservative renewable and green energy ventures added EUR 128 million to the investment, which will save EUR 18 million for all programs. The performance of the 1st ESCO also helped press for expenditure in the private sector. The loan is indeed an incentive policy, not only a subsidy system. There is a soft-term loan from the government of India to enable hotel owners utilize alternative technologies for water heating [29]. Thailand still has a number of lending programs. The 'Circulating Fund' is one of the loans run by DEDE in Thailand to finance energy use by 11 financial institutions. The Thailand Investment Board (BOI) is one of the initiatives for established entrepreneurs to encourage investment. In addition, the Thai government set up the "Cost Base" initiative in 2012 to enable citizens to use high efficiency electrical appliances.

\subsection{Contribute to Policy Targets}

Switching to SWH or a heat pump will reduce the tremendous electricity use that enables an energy schedule that is renewable. Thailand does not have a direct proposal for a transition in water heating technologies. As part of the guiding force towards achieving the Sustainable Energy Development Plan (REDP) under the Department of Alternative Energy Development and Performance (DEDE), SWH is one of the renewable energy technologies. In 15 years, REDP plans to grow green energy as primary energy for Thailand; by 2022, renewable energy would have to be used as $20.3 \%$ of overall energy [30].

While Thailand is a non-Annex I nation that is not dedicated to lowering greenhouse gas emissions, Thailand is able to help Annex I countries by selling carbon credits under the Thailand Greenhouse Gas Management Organization (TGO) Clean Development Mechanism (CDM). Under the CDM programme, the latest water heating technologies may be the target of Single Project Category 3 Energy Demands. At high levels, the hotel industry may reduce GHG emissions, especially large hotels that need a high volume of hot water. The evolving technology often profits from entering the CDM project and as current 1.90 percent of world data, growing Thailand's carbon credit sales [31].

In Thailand, there is a void in the expertise of technicians and handlers that can be a significant restriction to their preference. A large percentage of device failure was noticed immediately after SWH implementation. SWH and HP introduced their operation in Thailand 25 and 18 years ago, respectively, and yet they are not the widespread focus of customers.

Considering the above mentioned merits and demerits of water heating systems, the present investigation was taken to SWOT-AHP analysis on Solar Water Heater (SWH) and Heat Pump (HP) for the alternation of Instantaneous Water Heater (IWT) in hotel sector of Thailand.

\section{Methods}

We have conducted comprehensive literature in this research, which is a straightforward three-step method. Firstly, through literature review and expert interviews, we defined factors. Later, these factors were grouped into four SWOT-categories: Strength, Weakness, Opportunity and Threat. Secondly, collected factors had been weighed to identify the three most significant factors per SWOT group in 
each technology. Finally, a pairwise comparison of the factors by face to face interview and questionnaires was made to facilitate SWOT-AHP analysis. A comprehensive analysis of the literature review has established these identified factors under the Social Sciences Citation Index (SSCI) and the Science Citation Index Extended (SCI-EXPANDED) of the Web of Science Core Collection, which is a widely used website for studies. [32]. The prime points were taken into consideration to do this study for literature review were, and we identified a combination of following keywords: (resident* AND water) OR (water AND heat*) OR (Instantaneous AND water AND heat*). Next, the parameters for the quest are in English and released between 2006 and 2015 (Date search is November 2015). The resulting publications are 3,271. All publications were curtained again. The publications were chosen for 975 publications in Finance, Electricity Fuel, Environmental Engineering, Environmental Sciences and Environmental Studies. After that, they were evaluated by the title of the source, which allowed 701 publications. Finally, they were sorted based on the abstracts and titles. We considered 62 related full texts. For factor selection, all 62 full texts have been analyzed in-depth (Figure 1).

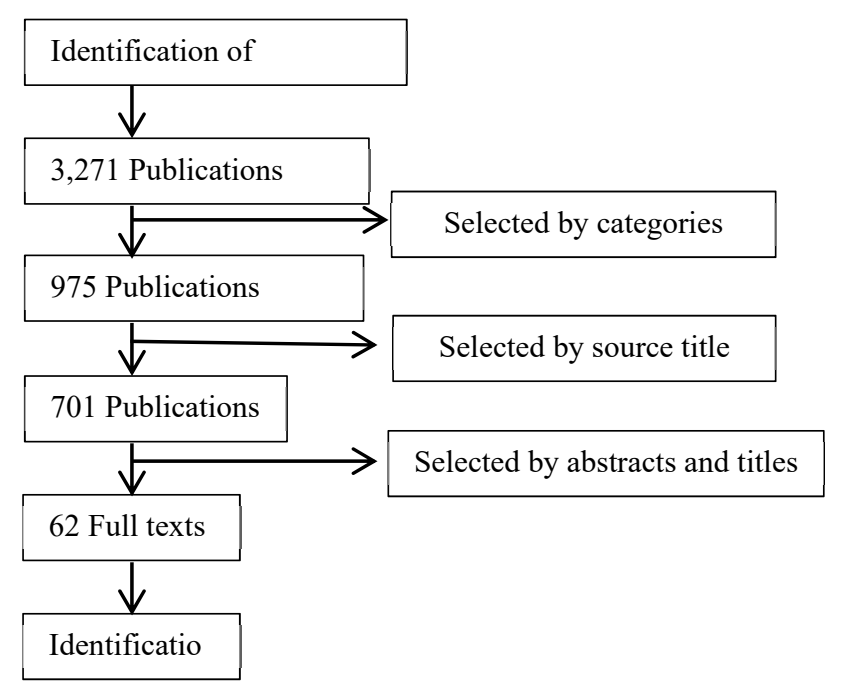

Figure 1. Flow chart of factor identification

Meanwhile, the conversation with specialists means that we do not skip any important variables. Experts are politicians, hoteliers, water heater companies and academia. They have adequate basic knowledge of Thailand, and all experts are Thai. As a consequence, their aspect linked to the situation in Thailand. The details can explain all aspects.

All factors were distinguished into four categories followed by a standard SWOT analysis: strengths, weaknesses, opportunities and threats. They were classified by some additional references to previous researches and experts' interview. Then, weighting each factor by important score. The three most essential factors per category were selected by weighting for representation in each group and each water heater technologies.

The hotel owners or managers in Southern/ Northern/ North-East and Central of Thailand were asked to make a pairwise comparison and weighting of the SWOT factors by face to face interview and questionnaires depending on water heater technology in that hotel. The comparison among all factors within a category is between the 4 SWOT categories are based on 9 point ranking as recommended by Saaty [33]. Each hotel had to make 18 pairwise comparisons in total. The integration between the AHP and SWOT analysis adjusts the accurate value of systematic priority ranking of factors. SWOT analyses are quantitative, not quality data. When hierarchic structure for AHP is chosen, which includes a goal making, an optimal decision on the most appropriate alternative could be. The SWOTAHP analysis is followed by three methods [34]:

1) 'local factor priority' by comparison between the factors in the same category of SWOT;

2) 'group priority' by comparison between the categories of SWOT;

3) 'global factor priority' by multiplying the 'local factor priority' and the respective 'group priority'.

4) Each factor calculation is in between $0-1$, based on the eigenvalue method.

The core concept of using the AHP inside the SWOT frame is to consistently test the SWOT variables to make them observable in terms of their weightiness [35]. The AHP structure results from the SWOT matrix in this analysis and is isolated and the SWOT structure's hierarchical representation is shown in Figure 2.

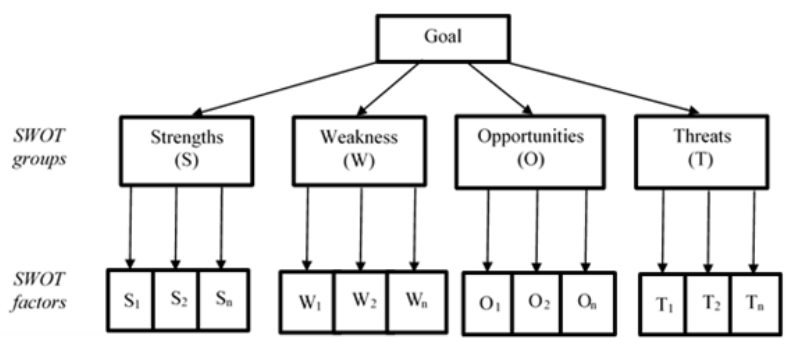

Figure 2. Hierarchical structure of the SWOT matrix

\section{Results}

We explored the findings of the SWOT-AHP study of various water heating technologies in Thailand. A collection of 33 variables was established based on the review of 62 research articles and 10 expert interviews. These considerations were organized according to a SWOT system for each of the technologies considered. Only the three most relevant factors per group were considered in order to 
promote more processing of the SWOT analysis using AHP. The three most significant considerations were chosen on the basis of expert interviews and literature review (i.e. frequency of occurrence in scientific papers).

\subsection{Instantaneous Water Heaters (IWH)}

In the hotel owner assessments of instantaneous water heaters, the positive factors, i.e. strengths and opportunities, clearly dominate. In the overall assessment, all six positive factors get better rankings than the six negative factors. Easy installation [S2] and low initial costs [S1] are considered most important, followed by easy availability / variety of buying channels [O2]. Safety issues [W2] are considered the most relevant weakness, followed by the high electricity consumption of such devices [W1]. Threats like financial support for alternative technologies or increasing awareness about energy efficiency are not considered to be of any significant relevance. Judging from the assessments made by hotel owners who adopt IWH, this technology seems to be solidified. Adopters are quite convinced by the technology, given the strong dominance of positive external and internal factors over negative factors. Thus, from their perspective it seems be a difficult task to push IWHs out of the market without firm policy measures.

Table 1. SWOT-AHP results for Instantaneous Water Heaters $(n=11)$

\begin{tabular}{|c|c|c|c|c|}
\hline \multirow{2}{*}{$\begin{array}{l}\text { SWOT factor } \\
\text { Strengths [Priority }=0.44]\end{array}$} & \multicolumn{2}{|c|}{ Local priority } & \multicolumn{2}{|c|}{ Global priority } \\
\hline & & & & \\
\hline $\mathrm{S}_{1}:$ Low initial cost & 0.36 & (2.) & 0.158 & (2.) \\
\hline $\mathrm{S}_{2}:$ Easy installation** & 0.43 & (1.) & 0.187 & (1.) \\
\hline $\mathrm{S}_{3}:$ Little space required & 0.21 & (3.) & 0.091 & (5.) \\
\hline \multicolumn{5}{|l|}{ Weaknesses [Priority $=0.14]$} \\
\hline $\mathrm{W}_{1}$ : High electricity consumption and bills & 0.33 & (2.) & 0.045 & (8.) \\
\hline $\mathrm{W}_{2}$ : Safety problem* & 0.57 & (1.) & 0.078 & (7.) \\
\hline $\mathrm{W}_{3}: \mathrm{CO} 2 / \mathrm{GHG}$ emission & 0.10 & (3.) & 0.014 & (12.) \\
\hline \multicolumn{5}{|l|}{ Opportunities [Priority $=0.35]$} \\
\hline $\mathrm{O}_{1}:$ Widespread in Thailand & 0.23 & (3.) & 0.080 & (6.) \\
\hline $\mathrm{O}_{2}:$ Variety of buying channels* & 0.43 & (1.) & 0.150 & (3.) \\
\hline $\mathrm{O}_{3}$ : Variety of price ranges and quality & 0.34 & (2.) & 0.120 & (4.) \\
\hline \multicolumn{5}{|l|}{ Threats [Priority $=0.08]$} \\
\hline $\mathrm{T}_{1}:$ Financial support for alternative technologies & 0.21 & (3.) & 0.016 & (11.) \\
\hline$T_{2}$ : Increasing awareness about energy efficiency* & 0.44 & (1.) & 0.034 & (9.) \\
\hline $\mathrm{T}_{3}$ : Mandatory policy plans for reducing energy consumption & 0.36 & (2.) & 0.028 & (10.) \\
\hline
\end{tabular}

* Factor with highest local priority in respective SWOT group

** Factor with highest local and global priority

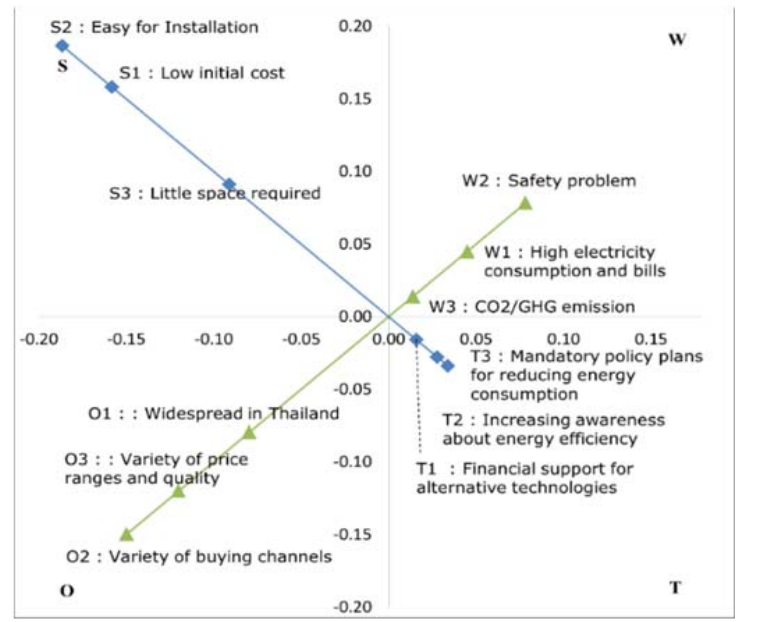

Figure 3. SWOT-AHP results for Instantaneous Water Heaters $(n=11)$

\subsection{Heat Pumps}

In the ranking of heat pump SWOT factors we observe that the importance of categories is well balanced; strengths and threats receive the highest ranking $(p=0.29)$, followed by weaknesses $(p=0.25)$ and opportunities $(p=0.16)$. The crucial SWOT factors are the relatively low energy consumption [S1], the lack of respective knowledge among installers [T1] and the high initial costs [W1]. These factors receive by far the highest rankings, and therefore should be in the center of attention when it comes to developing strategies for heat pump diffusion. It has to be noted that, other than in the analysis for IWHs, two of the three most important factors are from negative categories.

However, like in the assessments for IWH - which were made by different respondents - factors related to environmental and sustainability issues - i.e. low GHG emissions, contribution to environmental policy targets and the need for refrigerants - receive the lowest rankings. 
TEM Journal. Volume 10, Issue 2, Pages 498-507, ISSN 2217-8309, DOI: 10.18421/TEM102-03, May 2021.

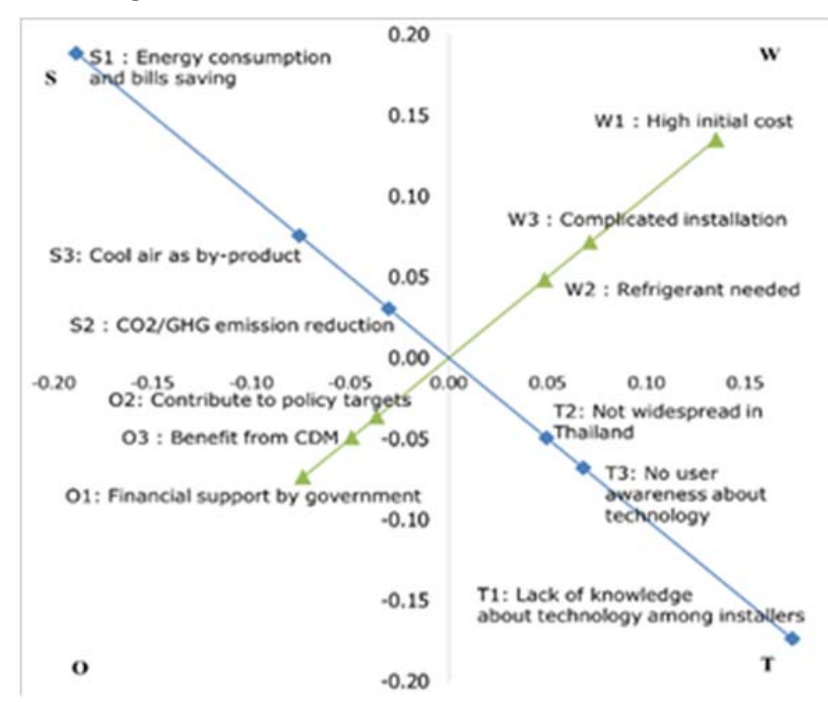

Figure 4. SWOT-AHP results for Heat Pumps (n=9)

Table 2. SWOT-AHP results for Heat Pumps $(n=9)$

\begin{tabular}{lcccc}
\hline SWOT factor & Local priority & \multicolumn{2}{c}{ Global priority } \\
\hline Strengths [Priority $=0.29]$ & & & & \\
$\mathrm{S}_{1}:$ Energy consumption and bills saving** & & & & \\
$\mathrm{S}_{2}: \mathrm{CO}_{2} / \mathrm{GHG}$ emission reduction & 0.64 & $(1)$. & 0.188 & $(1)$. \\
$\mathrm{S}_{3}:$ Cool air as by-product & 0.10 & $(3)$. & 0.030 & $(12)$. \\
\hline Weaknesses [Priority $=0.25]$ & 0.26 & $(2)$. & 0.076 & $(4)$. \\
$\mathrm{W}_{1}:$ High initial cost* & & & & \\
$\mathrm{W}_{2}:$ Refrigerant needed & 0.53 & $(1)$. & 0.135 & $(3)$. \\
$\mathrm{W}_{3}$ : Complicated installation & 0.19 & $(3)$. & 0.048 & $(10)$. \\
\hline Opportunities [Priority $=0.16]$ & 0.28 & $(2)$. & 0.071 & $(6)$. \\
$\mathrm{O}_{1}:$ Financial support by government* & & & & \\
$\mathrm{O}_{2}:$ Contribute to policy targets & 0.46 & $(1)$. & 0.074 & $(5)$. \\
$\mathrm{O}_{3}:$ Benefit from CDM & 0.23 & $(3)$. & 0.036 & $(11)$. \\
\hline Threats [Priority $=0.29]$ & 0.31 & $(2)$. & 0.049 & $(8)$. \\
$\mathrm{T}_{1}:$ Lack of knowledge on technology among installers* & & & & \\
$\mathrm{T}_{2}:$ Not widespread in Thailand & 0.60 & $(1)$. & 0.174 & $(2)$. \\
$\mathrm{T}_{3}:$ No user awareness about technology & 0.17 & $(3)$. & 0.049 & $(8)$. \\
\hline
\end{tabular}

* Factor with highest local priority in respective SWOT group

** Factor with highest local and global priority

\subsection{Solar Water Heaters (SWH)}

We found the importance of categories were welladjusted in the level of solar water heaters SWOT factors, while the strengths obtained the top ranking $(\mathrm{p}=0.65), \quad$ as followed by threats $(\mathrm{p}=0.16)$, weaknesses $(\mathrm{p}=0.11)$ and opportunities $(\mathrm{p}=0.08)$. The key SWOT factors are the significantly energy consumption and bills saving [S1], the lack of knowledge on technology among installers [T1] and the need back-up heating system [W3] because of seasonal trend of Thailand (especially raining season in Southern Thailand). These factors are accepted by the maximum rankings, and therefore should be focused of consideration when it moves toward to developing strategies for solar water heaters flow. It noted that, in the SWH analysis, two of the three most significant factors are from negative categories. On the other hand, the SWH assessments were done by not the same respondents.
The factors involved to sustainability as well as the environmental issues i.e. reduce GHG emissions, installation depend on building characteristic, benefit from CDM contribution and not widespread in Thailand were obtained in the lowest rankings.

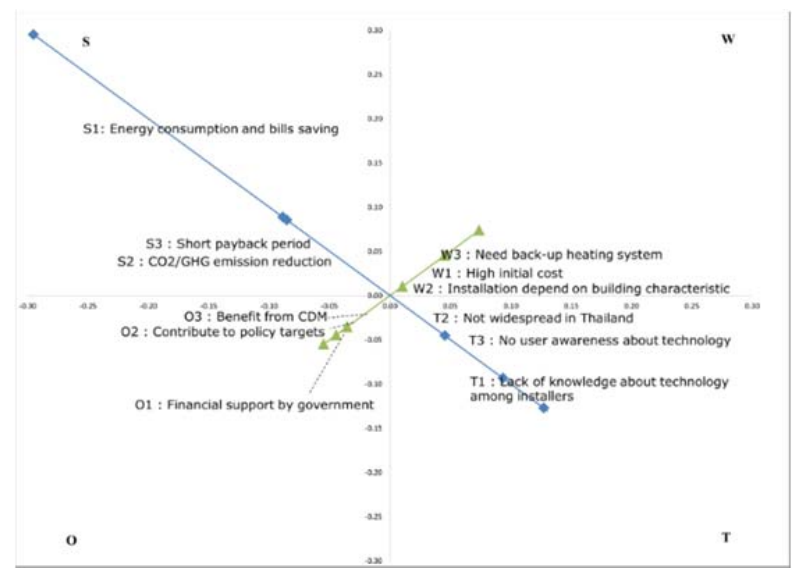

Figure 5. SWOT-AHP results for solar water heaters $(n=8)$ - to be replaced after $n$ has been increased 
Table 3. SWOT-AHP results for solar water heaters $(n=8)$

\begin{tabular}{|c|c|c|c|c|}
\hline \multirow{2}{*}{$\begin{array}{l}\text { SWOT factor } \\
\text { Strengths }[\text { Priority }=0.65]\end{array}$} & \multicolumn{2}{|c|}{ Local priority } & \multicolumn{2}{|c|}{ Global priority } \\
\hline & & & & \\
\hline $\mathrm{S}_{1}$ : Energy consumption and bills saving** & 0.63 & (1.) & 0.295 & (1.) \\
\hline $\mathrm{S}_{2}: \mathrm{CO} 2 / \mathrm{GHG}$ emission reduction & 0.18 & (3.) & 0.085 & (5.) \\
\hline $\mathrm{S}_{3}:$ Short payback period & 0.19 & (2.) & 0.089 & (4.) \\
\hline \multicolumn{5}{|l|}{ Weaknesses [Priority $=0.11]$} \\
\hline $\mathrm{W}_{1}$ : High initial cost* & 0.35 & (2.) & 0.045 & (8.) \\
\hline $\mathrm{W}_{2}$ : Installation depend on building characteristic & 0.08 & (3.) & 0.010 & (12.) \\
\hline $\mathrm{W}_{3}$ : Need back-up heating system* & 0.57 & (1.) & 0.074 & (6.) \\
\hline \multicolumn{5}{|l|}{ Opportunities [Priority $=0.08]$} \\
\hline $\mathrm{O}_{1}$ : Financial support by government* & 0.41 & (1.) & 0.055 & (7.) \\
\hline $\mathrm{O}_{2}:$ Contribute to policy targets & 0.33 & (2.) & 0.045 & (8.) \\
\hline $\mathrm{O}_{3}:$ Benefit from $\mathrm{CDM}$ & 0.26 & (3.) & 0.035 & (11.) \\
\hline \multicolumn{5}{|l|}{ Threats [Priority $=0.16]$} \\
\hline $\mathrm{T}_{1}$ : Lack of knowledge on technology among installers* & 0.48 & (1.) & 0.127 & (2.) \\
\hline $\mathrm{T}_{2}$ : Not widespread in Thailand & 0.17 & (3.) & 0.045 & (8.) \\
\hline $\mathrm{T}_{3}:$ No user awareness about technology & 0.35 & (2.) & 0.094 & (3.) \\
\hline
\end{tabular}

* Factor with highest local priority in respective SWOT group

** Factor with highest local and global priority

\section{Discussion}

We found a positive factor of IWH was an easy installation by local and global priority in SWOTAHP analysis. Similarly, low initial cost and little space required were beneficial aspect for IWS in boarding house area in Thailand. This indigenous system had several opportunities variety of buying channels, variety of price ranges and quality including widespread of the country. However, the SWOT-AHP analysis of IWH focused on safety problem as a main weakness. Moreover, it boosted a significant amount of power consumption [36], [37], [38] and emitted substantial greenhouse gases which are responsible for global warming. Taborianski \& Prado [39] discovered that through the emission of greenhouse gases that occur during the generation of electric power for the manufacture of components of this device, the IWH water heating systems will pollute the atmosphere. The findings also found that the electrical showerhead absorbs the most electrical resources for the adopted criteria and releases the most toxins over its life cycle. Increasing awareness about energy efficiency was great challenge of IHW in the SWOT-AHP analysis. This was very tough to overcome due to IHW consume huge energy. On the other hand, The SOWT-AHP analysis in response to HP was found three strengths namely energy consumption and bills saving, short payback period and reduction of greenhouse gas. Furthermore, we observed some opportunities as well. These strengths and opportunities factors may be the beneficial to the users. For example, compared to conventional electric water heaters, 70 percent of the energy could be saved by heat pump water heaters in China [40]. The benefit of utilizing heat-source-tower heat pumps in hot summer and cold winter zones and considered that they were ideal for usage in hotels and office buildings [41]. The USA noticed that electrical energy used by the land source heat pump was 53 percent smaller than the industry as normal (BAU). Heat pump devices in the UK are used as possible low-carbon heating systems for the future. New water heating systems in Japan will prevent the release of $12.5 \%$ of $\mathrm{CO}_{2}$ [42]. Approximately 36 percent of the Chinese group $(n=579)$ were concerned with environmental conservation, which is the most significant explanation for the shift in water heating technology in China [43]. It is claimed that the new generation of heat pump water heaters (HP) has efficiencies that are at least twice that of traditional electric water heaters in the United States. Accordingly, the electrical market for HP currently operational is usually one-half that of traditional electric water heaters which thus decreases the environmental effect of reducing greenhouse emissions relative to conventional electric water heaters [44]. But this water heating system had definite weaknesses and threats that was the key point for the adoption of HP water heating system. Predominantly, the high initial cost was found to be the basic weakness as well as complicated installation and refrigerant needed that made the adopter apathetic to use this heating system at all. Even though, SOWT-AHP analysis focuses on the empirical threats of water heating system HP. Besides, policy plans for reducing energy consumption are also involved in threats of HP. The policy for reducing energy consumption requires the implementation which is not an easy tax in a day. It is supposed to be required a long time for adoption in root level.

In the present research SOWT-AHP analysis on $\mathrm{SWH}$, we found a significant strength that $\mathrm{SWH}$ can decrease the energy consumption and bills saving. The SWH device produces end-use electricity savings of 12 to 20 percent of the gross electrical 
energy usage in Canada and Tunisia [45] while it can save approximately $50-85 \%$ in USA [46]. A major reduction in the power peak demand for energy by up to $70 \%$ was encouraged by the SWH. Using SWH in all provinces of Oman, for example, will save up to $1,859 \mathrm{GWh}$ of electrical energy annually [47]. In Malaysia, an average of $2108 \mathrm{kWh}$ of power can be saved by the implementation of the SWH [48]. The SWH device is often used in the household sector, as energy savings per household in the South will hit $130 \mathrm{kWh}$ per month. Again, the use of SWH has clear environmental consequences that will minimize the oil equivalent of 71,907 liters each year [49]. In SOWT-AHP analysis, we found some opportunities factors for SWH mainly financial support by government, benefit from CDM and contribute to policy targets. SWH has trivial factors on weaknesses and threats as well that were generally high initial cost and lack of knowledge on technology among installers. Sometimes, SWH need back-up heating system that involves extra financial monetary which creates burden to the consumers. It has also limitation on installation which depends on building characteristic. SWH did not widespread in Thailand that is also a threat to its prosperity. However, the SOWT-AHP analysis on the water heating system on HP, SWH along with IWH states a clear and informative knowledge that helps to the hotel owners, policy makers and also governmental authority for taking a decision making in water heating system in hotel sector in Thailand.

\section{Conclusion and Policy Implications}

Thailand's hot water system worth, seldom stated or quantified, is nearly 3,000 million Baht per year. Hotel area is the most significant hot water consuming sector due to Thailand is a tourist-based country at all. Therefore, the IWH is widely used in this particular sector frequently as for daily use. Due to excess energy consumption and also produce $\mathrm{CO}_{2}$ the greenhouse gas by IWH. Considering these facts, the present investigation was done to analysis SOWT-AHP for the alternate water heating system $\mathrm{HP}$ and SWH. In our research, the degree of importance or desirability for these strategic options is focused on the evaluation of its partnership with SWOT factors as parameters. The results revealed that all the three water heating system have significant strength, opportunities, weaknesses and threats in response to local and global priority. The findings of our study demonstrate that the instantaneous water heater (IWH) substituted by the alternate water heating technologies $\mathrm{HP}$ and $\mathrm{SWH}$ are largely reliant on external consumer influences. Assuming that it is feasible to address the key external obstacles, the experts consulted see great promise for alternative water heating technologies.
Basically, there appears to be a challenge with financial funding for alternative technology in the IWH scheme. However, some improvements are required at the present stage of water heating systems in Thailand's hotel sector to reduce energy, environmental and safety issues. The experts also gave preference to the technical expertise of both HP and SWH installers. These two alternative water heating system have significant strength to fulfill the less energy consumption and bills saving as well as it cool air by product. Moreover, the financial support by government is an opportunity for these twoalternative systems. However, to the degree that no room is left for personalized preparation, a strategy of optimizing organizational productivity should not be followed. Experience can decide in practice the right mix of goals.

To conclude, policy maker, political and technical impulses are still necessary in order to make the water heating system more convenient as it is the huge source of using energy in Thailand. Consequently, in the mid-term utilization it is unexpected to increase significantly in water heating system. In the long-term, however, the need to optimize the utilization of the HPs and SWHs are very likely to become established in hotel sector. It brings significant component of the energy system.

\section{Acknowledgements}

The author would like to thank Assistant Professor Dr. Thomas Brudermann and Dr. Ralf Aschemann, Karl Franzens Universitat, Graz, Austria. The financial support for this research is from Research and Researcher for Industry RRI (Ph.D. Level), The Thailand Research Fund (TRF) together with Advance Thermo Solution Co., Ltd.

\section{References}

[1]. Power Generation. (2019). Thailand Industry Outlook 2019-2021. Retrieved from:

https://www.krungsri.com/bank/getmedia/b2bac10fff94-4865-9561-

21f7d15e4dc6/IO Power Generation 190627 EN E X.aspx, [accessed: 10 December 2020].

[2]. Clemons, S. K. C., Salloum, C. R., Herdegen, K. G., Kamens, R. M., \& Gheewala, S. H. (2021). Life cycle assessment of a floating photovoltaic system and feasibility for application in Thailand. Renewable Energy, 168, 448-462.

[3]. Yasothorn, A., Teekasap, P., \& Teekasap, S. (2017). Energy conservation direction and economic growth. Journal of Renewable Energy and Smart Grid Technology, 12(2), 1-12.

[4]. Metropolitan Electricity Authority. (2013). The Saving of Electricity Usage. pp.11-20.

[5]. Srisangnam, P. (2019). Thailand at the Frontier of Upper Middle Income. In Southeast Asia and the ASEAN Economic Community (pp. 145-186). Palgrave Macmillan, Cham. 
[6]. National Statistical Office. (2016). Tourists' statistics, national statistical office of Thailand. Retrieved from: http://service.nso.go.th/nso/web/statseries/statseries23 .html . [accessed: 12 December 2020]

[7]. Thanksooks, J. (2014). The development of domestic hotels in Thailand:" tracing the past, seeing the present and predicting the future" (Doctoral dissertation, James Cook University).

[8]. Wilkenfeld, G. (2010). Phasing out greenhouseintensive water heaters in Australian homes. National Economic Review, (63), 26-37.

[9]. Van der Gaast, W., Begg, K., \& Flamos, A. (2009). Promoting sustainable energy technology transfers to developing countries through the CDM. Applied Energy, 86(2), 230-236.

[10]. Jingjit, S., \& Techato, K. (2016). Economic analysis of water heating technology in Thailand. Asia-Pacific Journal of Science and Technology, 21(4).

[11]. Colmenar-Santos, A., Vale-Vale, J., Borge-Diez, D., \& Requena-Pérez, R. (2014). Solar thermal systems for high rise buildings with high consumption demand: Case study for a 5 star hotel in Sao Paulo, Brazil. Energy and buildings, 69, 481-489.

[12]. Nikoofard, S., Ugursal, V. I., \& BeausoleilMorrison, I. (2014). An investigation of the technoeconomic feasibility of solar domestic hot water heating for the Canadian housing stock. Solar Energy, 101, 308-320.

[13]. Cassard, H., Denholm, P., \& Ong, S. (2011). Technical and economic performance of residential solar water heating in the United States. Renewable and Sustainable Energy Reviews, 15(8), 3789-3800.

[14]. Özdemir, E. D., Marathe, S. D., Tomaschek, J., Dobbins, A., \& Eltrop, L. (2012). Economic and environmental analysis of solar water heater utilisation in Gauteng Province, South Africa. Journal of Energy in Southern Africa, 23(2), 2-19.

[15]. Vieira, A. S., Beal, C. D., Ghisi, E., \& Stewart, R. A. (2014). Energy intensity of rainwater harvesting systems: A review. Renewable and Sustainable Energy Reviews, 34, 225-242.

[16]. Zambrana-Vasquez, D., Aranda-Usón, A., ZabalzaBribián, I., Janez, A., Llera-Sastresa, E., Hernandez, P., \& Arrizabalaga, E. (2015). Environmental assessment of domestic solar hot water systems: a case study in residential and hotel buildings. Journal of Cleaner Production, 88, 29-42.

[17]. Li, W., Song, G., Beresford, M., \& Ma, B. (2011). China's transition to green energy systems: The economics of home solar water heaters and their popularization in Dezhou city. Energy Policy, 39(10), 5909-5919.

[18]. Ruble, I., \& El Khoury, P. (2013). Lebanon's market for domestic solar water heaters: Achievements and barriers. Energy for Sustainable Development, 17(1), 54-61.

[19]. Chang, P. L., Ho, S. P., \& Hsu, C. W. (2013). Dynamic simulation of government subsidy policy effects on solar water heaters installation in Taiwan. Renewable and Sustainable Energy Reviews, 20, 385-396.
[20]. Donev, G., Van Sark, W. G., Blok, K., \& Dintchev, O. (2012). Solar water heating potential in South Africa in dynamic energy market conditions. Renewable and Sustainable Energy Reviews, 16(5), 3002-3013.

[21]. Giglio, T., Lamberts, R., Barbosa, M., \& Urbano, M. (2014). A procedure for analysing energy savings in multiple small solar water heaters installed in lowincome housing in Brazil. Energy Policy, 72, 43-55.

[22]. Cassard, H., Denholm, P., \& Ong, S. (2011). Technical and economic performance of residential solar water heating in the United States. Renewable and Sustainable Energy Reviews, 15(8), 3789-3800.

[23]. Fantidis, J. G., Bandekas, D. V., Potolias, C., \& Vordos, N. (2013). Cost of PV electricity-Case study of Greece. Solar Energy, 91, 120-130.

[24]. Houri, A. (2006). Solar water heating in Lebanon: current status and future prospects. Renewable energy, 31(5), 663-675.

[25]. Veeraboina, P., \& Ratnam, G. Y. (2012). Analysis of the opportunities and challenges of solar water heating system (SWHS) in India: Estimates from the energy audit surveys \& review. Renewable and Sustainable Energy Reviews, 16(1), 668-676.

[26]. Runqing, H., Peijun, S., \& Zhongying, W. (2012). An overview of the development of solar water heater industry in China. Energy Policy, 51, 46-51.

[27]. Brum, M., Erickson, P., Jenkins, B., \& Kornbluth, K. (2015). A comparative study of district and individual energy systems providing electrical-based heating, cooling, and domestic hot water to a low-energy use residential community. Energy and Buildings, 92, 306-312.

[28]. Goto, H., Goto, M., \& Sueyoshi, T. (2011). Consumer choice on ecologically efficient water heaters: Marketing strategy and policy implications in Japan. Energy Economics, 33(2), 195-208.

[29]. Veeraboina, P., \& Ratnam, G. Y. (2012). Analysis of the opportunities and challenges of solar water heating system (SWHS) in India: Estimates from the energy audit surveys \& review. Renewable and Sustainable Energy Reviews, 16(1), 668-676.

[30]. Department of Alternative Energy Development and Efficiency. (2011). Ministry of Energy, Thailand Energy Statistics. Retrieved from: http://www.eppo.go.th/index.php/en/enenergystatistics/electricity-statistic [accessed: 12 December 2020].

[31]. Thailand Greenhouse Gas Management Organization. (2014). Web-based Thai Carbon Footprint Calculator. Retrieved from: http://carbonmarket.tgo.or.th/carbonfootprint/thai/engi ne.php, [accessed: 14 December 2020].

[32]. Karakaya, E., \& Sriwannawit, P. (2015). Barriers to the adoption of photovoltaic systems: The state of the art. Renewable and Sustainable Energy Reviews, 49, 60-66.

[33]. Saaty, T. L. (1986). Axiomatic foundation of the analytic hierarchy process. Management science, 32(7), 841-855. 
[34]. Brudermann, T., Mitterhuber, C., \& Posch, A. (2015). Agricultural biogas plants-A systematic analysis of strengths, weaknesses, opportunities and threats. Energy Policy, 76, 107-111.

[35]. Kangas, J., Kurttila, M., Kajanus, M., \& Kangas, A. (2003). Evaluating the management strategies of a forestland estate - the SOS approach. Journal of Environmental Management, 69(4), 349-358.

[36]. Höhne, N., Fekete, H., den Elzen, M. G., Hof, A. F., \& Kuramochi, T. (2018). Assessing the ambition of post-2020 climate targets: a comprehensive framework. Climate Policy, 18(4), 425-441.

[37]. Yao, R., \& Steemers, K. (2005). A method of formulating energy load profile for domestic buildings in the UK. Energy and Buildings, 37(6), 663-671.

[38]. Bourke, G., Bansal, P., \& Raine, R. (2014). Performance of gas tankless (instantaneous) water heaters under various international standards. Applied Energy, 131, 468-478.

[39]. Taborianski, V. M., \& Prado, R. T. A. (2004, September). 04102572 Comparative evaluation of the contribution of residential water heating systems to the variation of greenhouse gases stock in the atmosphere. In Fuel and Energy Abstracts (p. 359).

[40]. Ni, L., Dong, J., Yao, Y., Shen, C., Qv, D., \& Zhang, X. (2015). A review of heat pump systems for heating and cooling of buildings in China in the last decade. Renewable Energy, 84, 30-45.

[41]. Zhang, X., Wen, X., \& Liang, C. (2013). New type of dual high-efficiency heat pump system suited to hot summer and cold winter zones. Refrigeration Air Condition, 13(11), 6-10.
[42]. Shimoda, Y., Okamura, T., Yamaguchi, Y., Yamaguchi, Y., Taniguchi, A., \& Morikawa, T. (2010). City-level energy and CO2 reduction effect by introducing new residential water heaters. Energy, 35(12), 4880-4891.

[43]. Han, J., Mol, A. P., \& Lu, Y. (2010). Solar water heaters in China: A new day dawning. Energy Policy, 38(1), 383-391.

[44]. Willem, H., Lin, Y., \& Lekov, A. (2017). Review of energy efficiency and system performance of residential heat pump water heaters. Energy and Buildings, 143, 191-201.

[45]. Nikoofard, S., Ugursal, V. I., \& BeausoleilMorrison, I. (2014). An investigation of the technoeconomic feasibility of solar domestic hot water heating for the Canadian housing stock. Solar Energy, 101, 308-320.

[46]. Cassard, H., Denholm, P., \& Ong, S. (2011). Technical and economic performance of residential solar water heating in the United States. Renewable and Sustainable Energy Reviews, 15(8), 3789-3800.

[47]. Al-Badi, A. H., \& Albadi, M. H. (2012). Domestic solar water heating system in Oman: Current status and future prospects. Renewable and Sustainable Energy Reviews, 16(8), 5727-5731.

[48]. Jing, O. L., Bashir, M. J., \& Kao, J. J. (2015). Solar radiation based benefit and cost evaluation for solar water heater expansion in Malaysia. Renewable and Sustainable Energy Reviews, 48, 328-335.

[49]. Yoo, J. H. (2015). Evaluation of solar hot water heating system applications to high-rise multi-family housing complex based on three years of system operation. Energy and buildings, 101, 54-63. 